\title{
Kjønn og feminisme i norsk filosofi
}

\author{
- Noen betraktninger ${ }^{1}$ \\ Inga Bostad \\ Direktør - Norsk senter for menneskerettigheter, \\ Universitetet i Oslo \\ inga.bostad@nchr.uio.no \\ Tove Pettersen \\ Professor i filosofi ved Insitutt for filosofi, idé- og kunsthistorie \\ og klassiske fag, og gjesteforsker ved Senter for tverrfaglig \\ kjønnsforskning, Universitetet i Oslo \\ tove.pettersen@ifikk.uio.no \\ English abstract p. 191
}

Norge regnes som et av verdens mest likestilte land, og har en høyt utdannet befolkning. I 2014 hadde nærmere én av tre høyere utdanning. Blant folk mellom 25 og 39 år har mer enn halvparten av kvinnene høyere utdanning, noe som gjør denne aldersgruppen til den høyest utdannede i Norge. ${ }^{2}$ Dette er en utvikling som har gått gradvis. Fra Cecilie Thoresen som første kvinnelige student i Norge ble immatrikulert i 1882, var kvinner frem til 1985 i mindretall ved norske universiteter. I 1985 var det for første gang flere kvinnelige enn mannlige studenter i Norge, og kvinneandelen har økt jevnt siden den gang. ${ }^{3}$

Kvinneandelen i filosofifaget utgjør imidlertid et betydelig avvik sammenlignet med den generelle utviklingen av kjønnsfordelingen ved de norske universitetene. Filosofifaget har blitt kalt en mannsbastion, og er et av de få fagene hvor mannsdominansen har holdt seg ganske konstant. ${ }^{4}$ Andelen kvinner som tok doktorgrad i filosofi i Norge i perioden 2010-2014, har gått ned fra 30 til 20 prosent, noe som er særlig interessant fordi det er så pass få i reelle tall (en nedgang fra 14 til 8 personer). Mens andelen menn som tok doktorgrad i perioden 2005-2009 var på 70 prosent, har den altså nå økt til 80 prosent i samme tidsintervall. Mannsdominansen i filosofi har med jevne mellomrom blitt debattert i media, undersøkelser har blitt gjennomført og tiltak iverksatt. I denne artikkelen skal vi komme med noen betraktninger om kvinners tilstedeværelse i norsk filosofi. Disse betraktningene bygger blant annet på de svarene sentrale personer i det norske filosofimiljøet - Synnøve des Bouvrie, Ingeborg W. Owesen, Kristin Sampson, Vigdis Songe-Møller, Ingebjørg Seip, Elin Svenneby og Else Wiestad - har gitt oss på spørsmål om kjønn og feminisme i filo- 
sofifaget. ${ }^{5}$ Vi omtaler den lave kvinneandelen blant studenter og ansatte i faget, deretter hvorvidt kjønnsperspektiver er til stede i filosofifaget, og avslutningsvis hvorfor kvinners lave deltakelse er et problem. Men aller først noen refleksjoner om selve tematikken som også forklarer hvorfor vi har endret vårt skriveoppdrag fra «Kvinner i norsk filosofi», til «Kjønn og feminisme i norsk filosofi».

\section{Om filosofer og kvinnelige filosofer}

Et fagfelt kan presenteres på flere måter: Fremstillingen kan organiseres kronologisk med fokus på enkeltpersoners bidrag og innflytelse. Fagfeltet kan også ordnes mer tematisk, slik redaktørene av dette nummeret av NFT har gjort, ved å dele norsk filosofi inn i ulike retninger og miljøer. Dette er velkjente organiseringsprinsipp som kan gjenfinnes i mange lærebøker og oversiktsartikler. Det er fordeler og ulemper ved begge prinsippene, men de genererer begge noen interessante problemstillinger når kjønn skal med.

Et problem knyttet til det å gi en egen fremstilling av kvinner, er at den kronologiske fremstillingen av fagfeltet da underforstått antas å bestå av bare menn: Skal kvinner med, må det være $\mathrm{i}$ form av et tillegg. I en kronologisk fremstilling av for eksempel

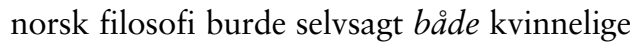
og mannlige filosofer bli presentert. Likevel har kronologiske fremstillinger ofte en egen tilføyelse - et avsnitt, et kapittel eller en egen artikkel - hvor kvinner omtales separat. Ingeborg Owesens artikkel «Om å kanonisere det som har unndratt seg kanonisering: feminisme og filosofihistorie» (2010) problematiserer nettopp det at stoff om kvinner samles til slutt, som et eget tillegg eller eget kapittel.

Nå er det ikke nødvendigvis problematisk å organisere kvinnelige og mannlige ${ }^{6}$ filoso- fer hver for seg. Det problematiske oppstår når én gruppe fremstilles som «filosofer", den andre som «kvinnelige filosofer». Denne organiseringen bygger på et kategorimistak, for inndelingen må enten være «norske filosofer», og inneholde både kvinnelige og mannlige filosofer, eller kjønnsdelt og da bestå av «kvinnelige filosofer» og «mannlige filosofer». Dersom kjønn skal være et organiseringsprinsipp for eksempel i fremstillingen av norsk filosofi, kan altså presentasjonen deles i to: Én artikkel om kvinnelige filosofer i Norge, en annen om mannlige.

Gitt det selvsagte i denne inndelingen, må vi spørre hvorfor tittelen «Mannlige filosofer i norsk filosofi» likevel klinger rart, mens få trolig vil reagere på tittelen «Kvinnelige filosofer i norsk filosofi»? Forklaringen er at skillet mellom «filosofer» og «kvinnelige filosofer» ikke bare representerer et tilfeldig asymmetrisk forhold mellom to kategorier. Det bygger også på et innflytelsesrikt syn på kjønn som går tilbake til Aristoteles' oppfatning av hva det er å være menneske. ${ }^{7}$ For Aristoteles er prototypen på et menneske den fullt utviklede, voksne mannen. Mannens fremste kjennetegn er rasjonalitet (logos). Kvinnen defineres med utgangspunkt i sin forskjellighet fra mannen; hennes fremste kjennetegn er hennes reproduktive kapasitet. Dermed blir hun også først og fremst et kjønnsvesen. Selv om Aristoteles i innledning til Politikken) beskriver kvinnen som det «redskap» mannen trenger for å føre slekten videre, beskriver han riktignok senere hvordan også kvinnen har en rasjonalitet. Dette er imidlertid en «umyndig» form for rasjonalitet (Aristoteles 2007, 60).

I innledningen til Det annet kjønn viser Simone de Beauvoir nettopp til Aristoteles' kjønnssyn, og hun reflekterer over en tilsvarende problemstilling; hvorfor skilles det 
mellom fotografer og kvinnelige fotografer, og hvorfor beskyldes Beauvoir selv for å mene noe bare fordi hun er kvinne mens en mann ikke beskyldes for å mene noe fordi han er mann? Hun skriver:

Bare det å ta opp problemet antyder straks et første svar. Det er betegnende at det er jeg [en kvinne] som tar det opp. En mann ville aldri ha kommet på den tanken å skrive en bok om hankjønnets spesielle situasjon blant menneskene. Hvis jeg vil definere meg selv, er jeg nødt til først å erklære «Jeg er en kvinne»; denne sannheten danner bakgrunnen som enhver annen påstand trer frem på. En mann starter aldri med å fremstille seg selv som et individ av et bestemt kjønn; det er en selvfølge at han er en mann (Beauvoir 2000, 35).

Dette er en del av filosofihistorien som er kjent for mange, men som likevel blir oversett. Vi mener bevisstgjøring av virkningshistorien av en slik kategorisering av kjønn, er viktig, og det er nødvendig å undersøke nåværende direkte og indirekte stereotypier av kjønn, rasjonalitet og naturlige egenskaper som følger denne inndelingen også i filosofien. Skillet mellom «filosofer» og «kvinnelige filosofer» - eller mellom artister og kvinnelige artister, fotball og kvinnefotball for den saks skyld - understøtter altså myten om at kvinner først er sitt kjønn, i motsetning til menn som først og fremst representerer mennesket. Denne asymmetriske inndelingen bidrar videre til å opprettholde forestillingen om at aktiviteten slik den utøves av menn utgjør standarden.

Med en slik forestilling er det også mulig å forklare hva ønsket om å ha en separat omtale av kvinner også i en tematisk fremstilling, kan bygge på: På samme måte som noen aktivite- ter omtales som «kvinnekunst» og «kvinnelitteratur», antydes det at det også finnes en «kvinnefilosofi». I alle disse nisjene er forestillingen at utøveren er opptatt av det «kvinnelige». Og siden det å være kvinne ikke først og fremst er å være menneske, men et kjønnsvesen, vil det som studeres og uttrykkes heller ikke være allmenngyldig. Det angår ikke mennesket som sådan, men er et utrykk for (enkelt)kvinners subjektive erfaringer.

Nå kan det høres ut som vi mener at kjønn er uten betydning. Det er ikke vårt standpunkt. I en kultur hvor kvinner og menn har ulik oppdragelse, ulike erfaring og blir møtt med ulike forventninger, spiller kjønn en avgjørende betydning for vår oppfatning av virkeligheten, for vår selvforståelse, våre mellommenneskelige relasjoner og vurderinger. Og fordi vi tror at filosofi ikke kan foregå fullstendig uavhengig av de enkelte filosofenes situasjon, er også kjønnede erfaringer av betydning for filosofien. Det er én grunn til at det er viktig å ha også kvinnelige filosofer representert på pensumlisten. Og derfor gir det også mening å spørre en filosof hva det har betydd for hennes filosofi at hun er kvinne. Det vi savner er tilsvarende refleksjon vedrørende menn: "Hvilken betydning har det hatt for din filosofi at du er mann?» «Hvordan har det påvirket din tenkning at alle de filosofiske verkene du arbeider med, er skrevet av menn?». "Hvilken betydning har det hatt at majoriteten av dine medstudenter og senere kollegaer, også er menn?».

\section{Kjønn i norsk filosofi - noen betraktninger}

\section{Den norske etterkrigsfilosofien}

I bøkene Filosofi på norsk (Bostad1995/97) forsøker en generasjon av norske filosofer å 
vise de store linjene i norsk filosofihistorie med særlig vekt på 50-, 60- og 70-tallet. Vi kan med utgangspunkt $\mathrm{i}$ disse analysene identifisere tre særpreg (eller omdreiningspunkter) i den norske etterkrigsfilosofien. Bildet som tegnes er preget av at Norge på 1950-tallet har hatt ett universitet siden 1811, og det er Universitetet i Oslo. Universitetet i Bergen er grunnlagt i 1946, så det er studietid og fagmiljø fra Oslo og etter hvert Bergen, som her står i sentrum. Men også Universitetet i Tromsø, som åpnet for undervisning september 1972, preget etter hvert norsk filosofi gjennom etableringen av det «radikale universitetet». ${ }^{8}$

\section{Dialektisk mangfold.}

Et kjennetegn ved den norske filosofien er en vedvarende spenning og utvikling mellom faglige motsetninger, som tidvis ga miljøet et nødvending mangfold. Et eksempel er omleggingen av ex.phil gjennom Arne Næss sin inntreden, $\mathrm{i}$ en vitenskapelig retning gjennom temaene tolkning og presisering, «bort fra den idéhistoriske danning (Winsnes og Skard) og psykologiske humanisme (Schelderup)» (Skirbekk 1996, 28). Et annet omdreiningspunkt var 1970-tallets spenning mellom den etablerte universitetsfilosofien, som var mer skolastisk og tradisjonsbunden ifølge den yngre generasjonen, og en mer politisk, handlingsrettet filosofi (Bostad 1996, Stigen 1973). Anklagene som kom fra de nyetablerte filosofene, var rettet mot at svært mye av den etablerte filosofien var opptatt av «menneskelig og samfunnsmessig sett unyttige konstruksjoner (Bostad 1996, 10). Samtidig beundret de «de eldres håndverksmessige evner, deres nøyaktighet og «vitenskapelighet» og deres evne til å lage filosofi på en intellektuelt sett uangripelig måte» (Stigen 1973).

\section{Revirtenkning og maktkamper.}

Et annet omdreiningspunkt i det norske filosofimiljøet er 1980-tallets konfrontasjon mellom «en gruppering av hovedsakelig etablerte (eldre) filosofer med en kontinental, metafysisk, moral-politisk orientering, og en mindre etablert (yngre) garde av mer anglo-amerikansk logisk-analytisk og språkfilosofisk interesse» (Bostad 1996, 10). Denne interessemotsetningen dreide seg $\mathrm{i}$ all hovedsak om endringer av pensum og av undervisningstilbudet.

\section{Nøytralitet og kjønnsblindhet.}

En tredje karakteristikk av den norske etterkrigsfilosofien kan knyttes til forestillingen om filosofiens kjønnsblindhet; det vil si en grunnleggende overbevisning om at det filosofiske subjektet er eller bør være, uten en biografi eller et sted å høre til.

Dette er i seg selv en problematisk forestilling, og den har blitt grundig utfordret. En rekke studier innen feministisk kunnskapskritikk (Harding 1991, Alcoff og Potter 1993, Anderson 1995, Benhabib et al. 1995 ) viser at det som i et fagmiljø oppfattes som etablerte sannheter, også står hevet over eller utenfor en undersøkende kritikk og er vevet sammen med en helhet av teoretiske, kulturelle og logiske forutsetninger jf. også Kuhns paradigmeteori (Kuhn 1962) ${ }^{9}$. For filosofer med en annen erfaringsbakgrunn enn flertallet i miljøet, slik tilfellet ofte er for kvinner i filosofi, kan forestillingen om det filosofiske subjektets kjønnsløshet medføre mange utfordringer, både teoretisk og praktisk. Det kan se ut som om det mannsdominerte norske filosofimiljøet i etterkrigstiden, slik det beskrives i ettertid, legger til grunn en forståelse av at filosofien er kjønnsnøytral, mens den feministiske epistemologien tar utgangspunkt $\mathrm{i}$ at de sosiale og diskursi- 
ve normene for utøvelsen av filosofi også er preget av utøverens egne erfaringer - inkludert kjønnede erfaringer.

Med utgangspunkt i disse to ulike posisjonene stiller vi følgende spørsmål: Hvor lett var det for de få kvinnene i det norske filosofimiljøet på slutten av 70- og 80-tallet å få innpass og markere seg når miljøet beskrives som preget av "practical jokes» 10 der «filosofane tedde seg rart - (og ein god del av dei kledde seg rart - beksomstøvlar med ryggsekk heller enn skjorte med slips)». (...) den folkelege stilen sat djupt hos guruar som Jakob Meløe og Hans Skjervheim - og disiplane deira følgde gjerne etter, i stil og i åtferd. ${ }^{11}$ I Filosofi på norsk beskriver Skirbekk 50-tallets filosofer som «ekspressive typar», «villmenn», «sindige karar» som «uvørent og skarrande vandra inn i Det Kongelige Frederiks» ${ }^{12}$.

Skirbekk beskriver det han ser, eller rettere sagt, tenker over at han så, i ettertid, og det er liten grunn til å være ironisk eller kritisk til det. Som en observasjon av det filosofiske miljøet, er denne karakteristikken likevel egnet til en større generalisering; å gjenfortelle denne typen forbindelse mellom fag og adferd, filosofi og representanter for filosofien, kan skape både bevisste og ubevisste stereotypier om hva norsk filosofi er og har vært. Vi leser Skirbekks skildring av de norske filosofenes uttrykk og atferd som en beskrivelse av en type maskulinitet, kanskje en norsk maskulinitet: Barske «villmenn» rett fra den norske fjellheimen ikledd beksømstøvler og ryggsekk, ikke skjorte og slips, som tramper inn på universitetet. Å følge etter den dominerende stilen er dermed med på å innsnevre filosofiens kjønn: Som et motsvar til «practical jokes» kledde for eksempel Inga Bostad seg én gang i semesteret $\mathrm{i}$ dress og slips når hun underviste i Det annet kjønn.
Else Wiestad beskriver erfaringene fra å være kvinne i dette mannsdominerte, maskuline men likevel kjønnsblinde filosofimiljø i Oslo, som å være "nykommer», "utenforstående» og «inntrenger» i en mannlig definert universitetskultur». «Student» var synonymt med «mann» ${ }^{13}$. Det var nettopp dette, fortsetter hun, som «fikk meg til å rette oppmerksomheten mot «kvinneblindheten» $\mathrm{i}$ faget. Det dreide seg for eksempel om taushet omkring kvinnerelevante problemstillinger (også kjente problemer som var høyst relevante for kvinner, som frihet, likeverd, likerett, makt/avmakt) og omkring kvinnelige filosofers bidrag til faget.» ${ }^{14}$

Else Wiestad beskriver videre filosofimiljøet i Oslo på en måte som understreker på det vi har kalt det dialektiske mangfoldet. Wiestad kaller det «pluralisme» og en «åpenhet for flertilnærminger».

Filosofimiljøet i Oslo møtte jeg i studietiden i to faser. Den tidlige i ca. 1962-63 var preget av pluralisme og Arne Næss' (nye) åpenhet for flertilnærminger til faget. Jeg hadde alt tatt tre andre fag, og begynte nå på filosofi. Foruten Næss, som underviste i Spinozas Etikk og den logisk orienterte Wienerskolen, holdt stipendiaten Hans Skjervheim seminar om eksistensialisme, Dag Østerberg om Merleau Pontys kroppsfenomenologi, Viggo Rossvær om Wittgenstein og Guttorm Fløystad om Heidegger. Disse unge stipendiatene hadde også tid til å diskutere i kantinene om filosofiske og andre emner, og flere gikk sammen på «Upopulær aften» i Dovrehallen der aktuelle temaer ble debattert. Miljøet var åpent og virket generelt interessant og stimulerende. Den neste perioden, fra ca. 1969-73, var i større grad preget av den politiske vendingen (studentopprøret). Samtidig gikk min tid nå til ma- 
gistergradsstudier og undervisning til exphil. Et studieår (1970-71) var jeg stipendiat ved Sorbonne i Paris. Jeg fortsatte deretter med undervisning til exphil samtidig som jeg tok magistergraden på avhandlingen «Frihet og erkjennelse». Arne Næss var på den tiden gått av som professor, og lærerne ved instituttet virket nå fjernere. Som magistergradsstudent var jeg i stor grad overlatt til å utforme egne studiemål og sørge for egen fremdrift.

Åpenheten og mangfoldet i miljøet, til tross for kjønnsblindheten, var med på å gjøre det mulig for Wiestad å finne sin egen vei. Med sin doktoravhandling fra 1986, Kjønn og ideologi: en studie av kvinnesynet hos Locke, Hume, Rousseau og Kant, ble hun den første i Norge som drøftet kjønnsperspektiver innenfor filosofien. ${ }^{15}$ Wiestad var ikke den eneste kvinnen i filosofifaget på denne tiden, men den eneste som gjorde kjønn til et tema. Som vi skal komme tilbake til, har dette bidratt til å gjøre Wiestad til en sentral person i utviklingen av den feministiske filosofien i Norge. Fra dette faglig sett pluralistiske og mangfoldige filosofimiljøet fikk også flere kvinner, som senere ble svært innflytelsesrike på ulike arenaer, sin utdannelse. Det var i dette miljøet Laura Grimm, den første norske kvinnen som tok magistergrad i filosofi, i 1941 skrev sin avhandling om ironi $^{16}$. Senere kom Else Margarete Barth, som tok embetseksamen i psykologi i 1958, og ble den første kvinnelige filosofiprofessor utgått fra et norsk miljø og internasjonalt kjent for sine arbeider i filosofi og argumentasjonsteori. Barth banet nye veier for filosofien, og allerede i 1976 introduserte hun kjønnsperspektiver i filosofien som et eget kurs for studentene i Leiden ${ }^{17}$. Hjørdis Nerheim og etter hvert Vigdis Songe-Møller, har fungert som viktige rollemodeller for kvinnelige filosofer og banet hver på sin måte vei for et mer åpent og mangfoldig filosofimiljø. Nerheim var den første kvinnelige filosofiprofessoren i Norden. I innledningen til boken Kvinneperspektivet i filosofien - Premisser for å forstå den moderne kvinnens situasjon (1991), skriver Nerheim at formålet med tekstutvalget i boken er

«å vise at filosofiens forsøk på å skape orden i tilværelsen tildeler kvinner den mest forunderlige plassering og natur i rasjonalitetens navn. Vår kulturelle overlevering er til bristepunktet fylt med motstridende og konfliktfylte paradigmer angående forholdet mellom mann og kvinne (...) ved å bli oss bevisst disse motsetningsfylte bilder i vårt «indre» oppnår man trolig større selvinnsikt og personlig frihet» $(1991,5)$.

For Nerheim er feminismen kjennetegnet av en likhet mellom kjønn «ut fra deres felles natur som frie personer» $(2010,6)$.

$$
\text { 1980-90 tallet }
$$

Når det gjelder filosofimiljøet fra 1980-90tallet, har vi ingen systematisk studie å vise til, men vi har, som tidligere angitt, spurt en stor andel av kvinnene som har vært i miljøet. Ingeborg Owesen fremhever studentmiljøet i Oslo på 90-tallet som inkluderende: «Studentmiljøet var også den gangen mannsdominert, det var kanskje derfor jeg så raskt ble inkludert, de ønsket seg nok flere kvinner. Noe annet som preget miljøet den gangen var en frykt for at analytisk filosofi helt skulle fortrenge den kontinentale tradisjonen.» 18

Spenningen mellom den analytiske og den kontinentale tradisjonen som preget det norske filosofimiljøet i tiårene etter krigen, 
når nye høyder på 80-tallet - omtalt av Bostad (1996) som «revirtenkning og maktkamp». Kontinentalfilosofien, som blant annet omfattet fenomenologi og eksistensialisme, blir på 1980-tallet supplert med nyere fransk filosofi - for eksempel Baudrillard Lyotard, Derrida, Kristeva, Irigaray og Cixous. Disse filosofene gikk gjerne under merkelappen "postmoderne», og ble møtt med kraftig motstand fra det norske filosofimiljøet. Jon Elster har siden 1983 iherdig kritisert det han omtaler som «fransk obskurantisme», og gjør det fortsatt. ${ }^{19}$ I artikkelen «Invitasjon til (kulturelt (?) sjølvmord?» (I985) introduserte for eksempel Hans Skjervheim Derrida ved å gi følgende advarsel: Den som gir etter for Derrida «kan verta førd av garde inn i ei privat forvilling, av verste fall av psykopatologisk slag» (Skjervheim 1992, 52). Skjervheim sammenlignet det å følge Derridas tenkning med å hoppe i Etna - altså selvmord. Til tross for motstanden, ble disse kontinentale filosofene likevel introdusert for hovedfagsstudenter i Oslo gjennom Else Wiestads filosofiundervisning på midten av 1990-tallet, hvor også Tove Pettersen var gjesteforeleser. Den åpenheten og «flerfagstilnærming» Wiestad viser til, og som var viktig for hennes faglige utvikling på 1960-70-tallet, er altså under sterkt press på 1980- og 90-tallet. Den generasjonen filosofer som var opptatt av kontinentalfilosofi, mister etterhvert innflytelse: Wiestad peker på at

«Instituttet gikk etter hvert inn for et grunnstudium (etter mønster fra USA) konsentrert om fire såkalte basisemner i filosofi: logikk, metafysikk, erkjennelsesteori og etikk. Det ble et mer fasttømret studium (frem til og med storfag), med mindre rom for nye spørsmål og problemstillinger».
Ingeborg Owesen sier det slik;

«at jeg er kvinne har selvsagt preget mitt intellektuelle arbeid. Langt de fleste tenkerne på pensum var menn, umulig å ikke legge merke til det. Det gjorde inntrykk å møte Simone de Beauvoir på pensum som ung student. Det forsterket lysten til å ville fortsette med filosofi. (...)».

Elin Svenneby beskriver filosofisk institutt i Oslo som en «samlingsplass for filosofisk dialog og konfrontasjon», og at det var på pauserommet kampene sto, der det

"pågikk politisk kamp mellom kompromissløse studenter. Nyfeminismen var i anmarsj, kampen om universitetet var i gang, demokratiseringsprosessene trengte seg på. Professorveldet måtte ta slutt! Samtidig var vi smertelig klar over at den kunnskapen de lærde satt inne med ikke kunne erobres med kamp og krav, men med en ydmyk holdning og en umulig 12 timers arbeidsdag på lesesalen. Heldigvis var vi fem jenter som begynte på grunnfaget samtidig, vi etablerte et kollokvium og bestemte oss for at vi skulle klare å spare tid og knekke pensumkodene sammen. Det lyktes.» 20

Det senere møtet med filosofimiljøet i Tromsø, beskriver Svenneby slik:

«I Tromsø traff jeg ikke bare filosofiske kolleger av begge kjønn, men kvinneforskere fra mange fag. Her ble det nødvendig å tenke nytt for en søring som hadde trodd at østlandsområdet var Norges intellektuelle sentrum. Her var det høyt under tak og himmel, både i og utenfor seminarrommene, og tid til utallige diskusjoner på kryss og tvers mellom fag og politikk». 
Men Tromsø preges ikke bare av åpenhet og tverrfaglighet: Synnøve des Bouvrie fremhever særlig hvordan «kampen om ex phil» er historisk interessant i ettertid fordi filosofimiljøet som ga seg ut for å være ekstremt progressivt og på de undertryktes side forskning for folket, væpna revolusjon sto det på veggavisene - var uimottakelige for undertrykkelsen av kvinner. Universitetet i Tromsø gjennomgår på 80-tallet blant annet en lang og heftig debatt om hvorvidt likestillingsperspektiver skulle inkluderes i ex phil. Det daværende likestillingsutvalget ved UiT ble utsatt for en langvarig motstand fra filosofimiljøet som varte i fire år; "til slutt kom filosofene med et, trodde de, avgjørende 16 siders notat, en detaljert argumentasjon for hvorfor «likestillingsperspektivet i ex.phil.studiet» var en umulighet» (...), men det endte med at rektor påla «Filosofiseksjonen å innarbeide likestillingsperspektiver i ex.phil.» ${ }^{21}$.

\section{0-tallet}

Nifus rapport om kjønn og forskning i Norge fra 2002 (skriftserie 15/2002) viser at kjønnsfordeling i filosofi og idéhistorie i Norge, er følgende: Kvinneandel av kandidater og stipendiater er om lag 1 av 3, mens den var 1 av 6 blant det faste personalet og 1 av 13 blant professorene. I løpet av hele 1990-tallet ble det bare avlagt 4 doktorgrader av kvinner, mot 45 av menn. I dag er det tre til fire kvinnelige professorer i filosofi ved UiO, to ved NTNU, to ved UiT og to ved UiB.

Den skjeve kjønnsfordelingen i filosofi har blitt viet oppmerksomhet flere ganger, og i 2000 var det en heftig debatt da kollegiet ved Universitetet i Oslo vedtok å øremerke faste og midlertidige post.doc-stillinger til kvinner. Arild Pedersen forsvarte denne ordringen mot dem som kalte dette for en «misforstått kvinnehjelp» som diskriminerte menn, ${ }^{22}$ og i Oslo ble det tilsatt én kvinne i filosofi som resultat av ordningen. Som følge av at Dag Øistein Endsjø meldte øremerkingen inn for EFTA-domstolen, ble ordningen imidlertid stoppet i $2003 .{ }^{23}$ Kritikere av EFTA-domstolens beslutning har argumentert med at vedtaket strider mot FNs kvinnekonvensjon. ${ }^{24}$

I 2001 ble det ved Avdeling for filosofi i Oslo nedsatt en arbeidsgruppe med det formål å finne ut hvorfor kvinneandelen i filosofi er så liten, samt hvilke virkemidler det kan være hensiktsmessig å bruke for å øke rekrutteringen. Det ble i den forbindelse gjennomført en spørreundersøkelse blant studenter uteksaminert i perioden 1990-1999. ${ }^{25}$

I 2005 gjennomførte også studenter på Humanistisk prosjektsemester en undersøkelse av den skjeve kjønnsfordelingen på filosofi i Oslo, og undersøkelsen fikk navnet «En av gutta». Humanistisk prosjektsenter påpeker at faget har en sterk mannsdominans, og konklusjonene av undersøkelsen oppsummeres slik:

\begin{abstract}
«Det kvinnelige mindretallet på filosofi sa i undersøkelsen at de følte den sterke mannsdominansen som en belastning, og oppga at innholdet og vinklingen på studiet er svært maskulint. Blant annet er få kvinnelige filosofer representert på pensumlistene og studentene møter få kvinnelige vitenskapelig ansatte; diskusjonene foregår på menns premisser osv. Miljøet oppfattes som ensformig og lite dynamisk. Imidlertid trives de bedre når de etter hvert absorberes i miljøet, og blir en av gutta». ${ }^{26}$
\end{abstract}

Studentene bak undersøkelsen identifiserte tre mulige hovedårsaker til den lave kvinneandelen: For det første «manglende kvinne- 
lige rollemodeller på pensum og blant vitenskapelig ansatte», for det andre «et maskulint miljø som ubevisst ekskluderer kvinner», og for det tredje at "[f]agfilosofiens sterke analytiske karakter bidrar til at kvinner med en interesse for andre retninger innenfor filosofifaget kan mistrives». Informantene $\mathrm{i}$ undersøkelsen påpekte at «kvinnelige filosofer må inn på pensum, og at instituttet må jobbe aktivt for å få flere synlige kvinner i fagmiljøet». ${ }^{27}$ Denne undersøkelsen ledet til en heftig debatt i blant annet Universitas, hvor mange uttalte seg om «Kønnsproblemer i filosofi».

I en landsomfattende undersøkelse, gjennomført av Forskningsrådet for perioden 2004-2008, publisert i 2010, blir det igjen pekt på at den samlede andelen kvinner i filosofi er lav. Bare 25 prosent av studentene ved filosofistudiet i Norge er kvinner. 74 prosent av doktorgradsstipendiater og andre i rekrutteringsstillinger i filosofi er menn. ${ }^{28}$ Men, som Cathrine Felix (2010) påpeker; «til tross for dette åpenbare gapet mellom kjønnene - og uttalelsene fra intervjuobjektene, nevner utvalget overhodet ikke «kjønn» når det legger frem sin oversikt over det som betraktes som de største utfordringene norsk filosofi står overfor». Felix setter selv frem en liste med konkrete forslag til hva som kan gjøres for å øke antallet kvinner i norsk filosofi. ${ }^{29}$

Haakon Flemmen (2011) skriver i artikkelen «Færre kvinner tar doktorgraden» at andelen kvinner som tar doktorgrad i idéhistorie og filosofi «er gått ned fra 36 prosent i perioden $2005-2007$, til 20 prosent i 2008-2010». Her skilles det ikke mellom idéhistorie og filosofi, men Vigdis SongeMøller som den gang var leder for Institutt for filosofi og førstesemesterstudier ved
Universitetet i Bergen, kommenterer nedgangen på følgende måte:

«Man kunne ha håpet at kvinner etter hvert hadde funnet seg bedre til rette i filosofien, men det ser altså ikke ut til å være tilfelle. Én grunn til dette kan være at de dominerende retningene innen dagens filosofi ikke har tatt inn over seg fagets opplagte kjønnsdimensjon. Her kan det se ut som om andre humanistiske og samfunnsvitenskapelige fag er kommet lengre enn filosofi. En annen grunn er antakelig historiens gjentakende karakter: filosofi har tradisjonelt vært et fag utformet av menn og for menn, innhyllet $\mathrm{i}$ en intellektuell aura av kvasimaskulin karakter. Eller sagt på en annen måte: Det kan se ut som om unge menn lettere identifiserer seg med den dominerende filosofiske diskursen, mens den virker fremmedgjørende på mange unge kvinne». 30

Det må også nevnes at det har blitt publisert en rekke bøker og artikler om kjønnsperspektiver i filosofien på norsk; blant annet Else Wiestads De store hundreairsbølgene (1994), Vigdis Songe- Møllers (1999) Den greske drømmen om kvinnens overflødigbet, Hilde Bondevik og Linda Rustads Kiønnsperspektiver $\quad i$ filosofihistorien (1999), Elin Svennebys Også kvinner, Glaukon! (1999), og Tove Pettersens bok Filosofiens annet kjønn (2011). Filosofitidsskriftet Agora kom med et temanummer om feminisme i 2001 og siden med et eget nummer om Julia Kristeva (2003). Norsk filosofisk tidsskrift hadde feministisk filosofi som temanummer i 2007, og et av Filosofisk supplement temanumre i 2013 handlet om feminisme. 
Selv om vi ikke har hatt tilgang til alle publikasjoner, undersøkelser og tiltak som kan fortelle noe om kvinners tilstedeværelse i filosofien i Norge, fremgår det likevel tydelig at kvinner gjennom hele etterkrigstiden og frem til i dag har vært i klart mindretall og at filosofifaget er en svært mannsdominert disiplin. Det finnes statistikk som viser en tydelig skjev kjønnsfordeling, og intervjuer som forteller at mange kvinnelige studenter og ansatte føler mannsdominansen som en belastning ${ }^{31}$. Kjønnsskjevheten i filosofi har også jevnlig vært et tema i media. Gjentatte ganger har det blitt pekt på at faget mangler kjønnsperspektiver, fravoret av kvinnelige filosofer på pensumlistene har blitt kritisert, og konkrete forslag til tiltak har vært fremmet. Vi mener det ville være interessant å få en systematisk gjennomgang av hvor mange av disse forslagene som faktisk har blitt fulgt opp, og en vurdering av hvilken effekt disse kan ha hatt. Vårt materiale viser videre at tiltakene for å bedre kjønnsbalansen i filosofi og forsøkene på å integrere kjønnsperspektiver i faget, har møtt hard motstand. Vi synes også det er et påfallende samsvar mellom Else Wiestads karakteristikk av filosofifaget i Oslo på begynnelsen 1960-tallet, som preget av en «kvinneblindhet», som taust "omkring kvinnerelevante problemstillinger» og «omkring kvinnelige filosofers bidrag til faget», det filosofistudentene i Osloundersøkelsen i 2005 uttrykker, nemlig at «innholdet og vinklingen på studiet er svært maskulint» og at det «er få kvinnelige filosofer representert på pensumlistene», og Cathrine Felixs og Salongens nylige artikler som er kritiske til kvinners fravær i filosofifaget. Spørsmålet blir dermed om ingenting har skjedd siden 1960-tallet?

En stor forskjell mellom filosofifaget på 1960-tallet og på 2000-tallet, er at fagdisi- plinen feministisk filosofi har blitt etablert. Feministisk filosofi er nettopp en tilnærming til filosofi hvor kjønn står sentralt, og det er med utgangspunkt i erkjennelsen av at kjønnede erfaringer har betydning for kunnskapsproduksjon at denne disiplinen har vokst frem. Feministisk filosofi er en retning innenfor filosofien som undersøker hvilken betydning kjønn har for konstruksjon av filosofiske teorier og fremstillinger - feministisk etikk, feministisk epistemologi, feministisk metafysikk og feministisk filosofihistorie er eksempler - og som forsøker å korrigere for manglende kjønnsperspektiver. Feministisk filosofi vokste frem som en egen disiplin i forlengelsen av kvinnebevegelsen på 1960- og 1970-tallet, hovedsakelig i USA, da også filosofer begynte å problematisere mangelen på kjønnsperspektiver i sitt eget fag. Vi skal i resten av artikkelen komme med noen betraktninger om den feministiske filosofiens status i Norge. Studiet av feministisk filosofi og dens innflytelse og posisjon i Norge, er vel egnet til å gi oss et rikere og mer komplekst bilde av norsk filosofi. Det kan fortelle noe om hvor åpne eller lukkede de filosofiske miljøene er, men den kan også vise hvordan filosofien selv kan virke kunnskapskritisk gjennom selvrefleksjon, åpenhet og vedvarende kritisk overprøving av egne sannheter. Denne sensitiviteten for kjønnsperspektiver peker utover seg selv; den gir oss et aktuelt eksempel på en pågående fagutvikling og de (ofte usynlige) mekanismer som eksisterer.

\section{Feministisk filosofi i Norge - noen betraktninger}

Ellen Mortensen skriver i sin artikkel «Feminist Philosophy in Norway, with a View to the Other Nordic Countries» ${ }^{32}$ at den feministiske filosofien i Norge har hatt dårlige 
kår. Foruten å ha vært dypt preget av Else Wiestad og Vigdis Songe-Møller, er det riktig å si, ifølge Mortensen, at engasjement i feministisk filosofi for de fleste har gått på bekostning av akademiske karrierer. Først i de senere årene har den feministiske filosofien bredt om seg, både fordi universitetene har innført kjønnsforskning som egne studier, og fordi den norske velferdsstaten har forsvart og iverksatt en likestillingspolitikk. «This has created a climate of general acceptance of feminist issues and even a demand for feminist knowledge in Norway as in the other Nordic countries» skriver Mortensen. ${ }^{33}$

På Universitetet i Oslo har det ved Senter for tverrfaglig kjønnsforskning (STK) vært undervist i feministisk vitenskapsteori siden starten på 2000-tallet, og for filosofene har bacheloremnet «Kjønn og filosofi» eksistert siden 2004. Tilblivelsen av dette siste emnet illustrerer godt Mortensens poeng om hvor viktig den norske likestillingspolitikken og universitetets kjønnsforskning har vært for å få kjønnsperspektiver inn i filosofifaget. I et intervju med Bulletine i 2014 svarer Tove Pettersen, ansvarlig for emnet siden oppstarten, slik på spørsmålet om hvor viktig det var at noen påvirket utenfra for å få på plass et filosofiemne med fokus på kjønn: «Det var helt avgjørende. STK hadde lagt merke til at det hadde blitt fremmet flere forslag i fagrådet om å få inn emner med kjønnsperspektiv. Stort sett var det Else Wiestad og jeg som stod bak disse forslagene, men vi fikk ikke gjennomslag. Når så initiativet fra STK kom-STK oppfordret instituttet direkte om å etablere et kjønnsemne som kunne inngå i deres egen bachelorgrad -visste instituttet at Else og jeg var interessert $\mathrm{i}$ å etablere et slikt emne. De spurte oss, og vi sa ja. Da skjedde det plutselig mye på kort tid: Instituttet la forholdene til rette, Else og jeg utformet em- net, og studentene meldte sin interesse. Nå er dette et veletablert og relativt stort emne på IFIKK, og det har blitt tilbudt hvert vårsemester i ti år. Historien bak emnets tilblivelse er et godt eksempel på hvorfor man ofte må arbeide på flere steder samtidig, både innenfra og utenfra, for å få til endringer. Hvis et av disse elementene hadde vært borte, hvis ikke Else og jeg hadde vært der for eksempel, hadde det vært mye vanskeligere å få det iverksatt, og hvem vet hvor lang tid det hadde tatt. Men uten initiativet fra STK, hadde vi kanskje fortsatt sittet der og fremmet forslag. Når man jobber i fagmiljøer der kjønnsperspektiver ikke er ivaretatt, er det derfor avgjørende at de som er interessert i kjønn, gjør seg synlige og markerer sin interesse slik at man kan samarbeide - også på tvers av faggrenser og institusjoner.» ${ }^{34}$ Det kan også legges til at «Kjønn og filosofi» utgjør grunnlaget for at masteremne «Feministisk etikk» ble opprettet i 2011. I Oslo finnes det også siden 2003 kjønnsperspektiver i ex.phil, også der som et resultat av eksternt press: Universitetsstyret (den gang Kollegiet) fattet vedtak om at kjønnsperspektiver skal være representert på pensum til ex.phil i Oslo. Integrering av kjønnsperspektiver er altså ikke resultat av et eksplisitt ønske fra flertallet i fagmiljøet om å endre på skjev kjønnsbalanse, men skyldes eksternt påtrykk. Etter at Else Wiestad gikk av for aldersgrensen, er det i Oslo bare Tove Pettersen som har feministisk filosofi som kompetanseområde. Instituttet har i dag ingen planer om å styrke dette feltet.

Ingeborg Seip beskriver situasjonen i Trondheim på følgende måte: «I Trondheim er feministisk filosofi et felt som få lærere har kompetanse på eller interesse for, og som dessverre helt er fraværende fra fellespensum. Så lenge det stort sett ikke undervises i og 
holdes utenfor obligatorisk pensum, også der det ville vært en naturlig del, som i etikk og vitenskapsteori, blir inkompetansen selvreproduserende. Feministisk filosofi framstår som nærmest ikke-eksisterende og uviktig. Men når jeg en sjelden gang får holde et undervisningsopplegg i feltet, som spesialemne eller i andre forelesningsrekker der jeg kan velge pensum, strømmer studentene til, både gutter og jenter, og er veldig interesserte og positive. Problemet er altså ikke mangel på aktualitet eller interesse blant studentene, men manglende vilje hos lærerstaben til å utfordre innholdet i den filosofiske kanon.»

Ved Universitetet i Bergen har Kirsten Samspon feministisk filosofi som et av sine kompetanseområder, og underviser på emnet «Filosofi og kjønn». I Forskningsrådets rapport blir det påpekt at i Bergen har antikkgruppen også vært aktiv i internasjonale prosjekter knyttet til feministisk filosofi, noe som gjør at de skiller seg fra antikkgruppen i Oslo.

Elin Svenneby kom til Universitetet i Tromsø i 1987 som universitetsstipendiat med temaet «Kjønnsroller og likestilling i filosofien», og fikk høsten 1997 stilling som førsteamanuensis med plikt til å bygge opp og drive studieprogrammer og forskning innen feministisk filosofi samme sted. I dag er situasjonen for den feministiske filosofien ved Universitetet i Tromsø ganske oppløftende: Kjersti Fjørtoft forteller følgende: «I Tromsø har vi lenge hatt et kurs i feministisk filosofi. Kurset er også obligatorisk for de som tar årsstudiet i kjønnsstudier. Tidligere var det ikke så mange filosofistudenter som tok dette kurset, men nå er det langt flere, både menn og kvinner. Det tyder på at feministisk filosofi etter hvert blir oppfattet som en naturlig del av filosofifaget. Jeg har også inntrykk av at den yngre generasjonen filosofer i større grad integrerer kjønnsperspektiver på pensumlister og i fors- kningsprosjekter enn det som var vanlig tidligere. I alle fall er dette tilfelle i Tromsø. Jeg har også inntrykk av at vi som arbeider, eller har arbeidet med feministisk filosofi, i større grad engasjerer oss i tverrfaglige prosjekter.» UiT er, så vidt vi kjenner til, det eneste universitetet som eksplisitt har inkludert feministisk filosofi som et prioritert fagområde i perioden 2008-2012. ${ }^{35}$

At et eller to emner i feministisk filosofi tilbys mer eller mindre regelmessig, er selvsagt en stor forbedring i forhold til å ikke ha noen kjønnsemner. Studenter kan nå, i motsetning til for noen tiår tilbake, finne kjønnsperspektiver også i filosofifaget. Sett utenifra, viser også instituttenes emneporteføljer nå at kjønnsperspektiver finnes i faget, og når de feministiske emnene inngår i en evaluering av pensumlistene, vil det fremkomme at også kvinnelige filosofer er med. Filosofifaget kan dermed ikke lenger sies å være fullstendig kjønnsblindt. Langt på vei tilfredsstilles dermed også eksterne forventninger som springer ut fra universitetenes og Forskningsrådets likestillingspolitikk. Internt kan imidlertid etableringen av egne kjønnsemner medføre at alt som har med kjønn å gjøre, blir isolert til disse emnene, og dermed kan instituttenes øvrige emner fortsette uendret - det vil si uten at kjønnsperspektiver er med eller at tekster skrevet av kvinnelige filosofer, tas inn på pensumlisten. ${ }^{36}$ Slik sett kan kjønnsblindheten fortsette å eksistere i alle andre emner enn de som spesifikt fokuserer på kjønn og feministisk filosofi. Når kjønnsperspektiver og tekster av kvinnelige filosofer isoleres til egne emner, kan dette videre oppfattes som noe perifert, som noe for spesielt interesserte, fremfor et perspektiv som har relevans for de fleste delområder innenfor filosofien. Dermed opprettholdes den asymmetriske 
inndelingen vi nevnte innledningsvis; det finnes (ekte) filosofiemner hvor det fokuseres på det allmennmenneskelige, og det finnes kvinnefilosofi hvor fokuset er det subjektive og partikulære.

At kjønnsemner nå finnes ved de ulike lærestedene, betyr heller ikke at den feministiske filosofien står sterkt eller er godt integrert i filosofifaget. Fremfor å være en prioritert og selvsagt del av emneporteføljen ved de filosofiske instituttene - med Tromsø som unntak - samt et integrert perspektiv i de fleste filosofiemnene, befinner kjønnsperspektivene seg i utkanten av filosofifaget. Som Ingebjørg Seip peker pa ${ }^{37}$ : Så lenge det store flertallet av lærerstaben ved de filosofiske instituttene verken har interesse eller kompetanse innenfor dette feltet, og det heller ikke er planer om å utvide kompetansen, blir inkompetansen selvreproduserende. Dette, samt det faktum at eksistensen av feministisk filosofi ved de ulike universitetene synes å være avhengige av en eller to enkeltfilosofers engasjement og kompetanse, gjør den feministiske filosofien til en sårbar disiplin i Norge.

Med opprettelsen av emner i feministisk filosofi har altså kjønnsperspektiver gått fra å være ikke-eksisterende, til å erobre en marginal og utsatt plass i filosofifaget i dag. Kjønnsblindhet dominerer fortsatt, også i et av verdens mest likestilte land. Dette til tross for at undersøkelser de siste tiårene slår fast at mange (særlig kvinnelige) studenter ønsker at kjønnsperspektiver skal integreres, at de som underviser i disse emnene opplever at de er etterspurt blant studentene og at den skjeve kjønnsfordelingen og mangel på kjønnsperspektiver mange ganger har vært et tema i media. Kvinner i filosofifaget både studenter og ansatte - har prøvd å endre på dette også ved å danne flere nettverk: I Bergen finnes «Bergensnettverket for kvin- ner i filosofi» som har som formål å styrke kvinneandelen i filosofifaget ${ }^{38}$, i 2006 ble Sophia - nettverket for kvinnelige filosofistudenter i Oslo - startet ${ }^{39}$, og det finnes et felles nordisk nettverk, The Nordic Network for Women in Philosophy - som ble etablert i 1991 og hvor den andre konferansen ble avholdt i Bergen i 1993, med påfølgende publikasjon (Elin Svenneby og Inga Bostad 1993). Likevel er kjønnsperspektiver i filosofifaget fortsatt sjeldne, og pensumlistene er fremdeles svært mannsdominerte. Det er samtidig viktig å legge til at også mannlige filosofer integrerer feministisk filosofi i sine arbeider, for eksempel Odin Lysaker og Andreas Føllesdal.

\section{Hva er det med feministisk filosofi?}

Hva skyldes det at den feministiske filosofien ikke er bedre integrert og har høyere prioritet i det norske filosofimiljøet? Forklaringene kan være mange. Én grunn, som vi skal fokusere på her, kan være at den feministiske filosofien utfordrer noen grunnleggende antakelser i den mer tradisjonelle filosofien, og at den tar opp nye problemstillinger på nye måter slik at den fremstår som fremmed og provoserende for mer tradisjonsbundne filosofer.

Seip formulerer det slik: "En innsikt vi finner både i den klassiske vitenskapsteorien og i kritisk teori, såkalt poststrukturalisme og feministisk teori er nettopp beskriverens situerthet, det finnes ikke et nøytralt sted å beskrive fra. Vi forstår verden fra det konkrete stedet vi er, og denne posisjonen er alltid gjennomkrysset av normative føringer vi ofte ikke er bevisste på. Samtidig jobber vi kontinuerlig med å luke ut de normative feilslutningene, hvor vi glir fra beskrivelse eller forutsatt forståelsesramme til norm. Dette tror jeg er en uendelig prosess som er 
en integrert del av den filosofiske praksisen.»

Og Seip fortsetter slik: «Feministisk filosofi er jo ikke én ting, men mange forskjellige teorier som arbeider innen forskjellige tradisjoner og ofte er innbyrdes uenige. Likevel er det noen fellestrekk i feministisk refleksjon som jeg mener det er viktig at filosofien for øvrig tar inn over seg. Fordi feministisk teori forholder seg til den kjønnede kroppen, på den ene eller den andre måten, gjør den oppmerksom på menneskets kroppslige situerthet og hvilken rolle de sosiale og fysiske faktorene spiller for forståelsen. Samtidig skriver kvinner ofte litt «fra siden", fordi vi har erfaringer utenfor de tradisjonelle akademiske rammene, og derfor kan se ting på nye måter. Feministisk filosofi er mer reflektert enn annen filosofi både på menneskets kroppslige situerthet og på de kulturelle føringene som etablerer og opprettholder strukturelle forskjeller i denne situertheten. Innenfor svært mange tradisjonelle filosofiske diskurser, som spørsmål om objektiv kunnskap, etiske valg, estetiske dommer, forholdet mellom natur og kulturell pregning, kropp og bevissthet, individ og samfunn, burde feministiske teoretikere blitt sett på som naturlige deltakere i diskusjonen. Jeg tror de holdes utenfor av en blanding av inkompetanse, ideologi og manglende nysgjerrighet.»

Ifølge Owesen er «tenkning og erfaring (er) nært knyttet sammen, feministisk filosofi kan bidra til å avdekke forestillingen om filosofiens subjekt som en kjønnsløs størrelse. Slik sett kan feministisk filosofi også åpne for at andre erfaringer kan sette sitt preg på filosofien, som etnisitet.»

Tove Pettersen sier at «[d]en feministiske filosofien legger til grunn at aktøren - både som tenkende og handlende menneske - er situert. Da kommer man ikke unna det fak- tum at kvinner og menn tradisjonelt har vært situert svært forskjellig. Dette gir forskjellige erfaringer. Når man har forskjellige erfaringer, vil man også ha forskjellig perspektiv på hva som er de store moralske og politiske utfordringene, på hva som er viktig kunnskapsgrunnlag når man skal ta etiske beslutninger, på hva som teller som filosofi og så videre.» ${ }^{40}$ I boken Filosofiens annet kjønn skriver Pettersen at «den filosofiske forskningen om kjønn stimulerer til viktig faglig selvrefleksjon, til innsikt i nye og uutforskede aspekter ved tradisjonell filosofi. Reflekterer man over forholdet mellom kjønn og filosofi oppstår det [...] nye svar på og begrunnelser for velkjente problemstillinger, [det] skapes mulighet for å stille originale og utradisjonelle filosofiske spørsmål - ofte om temaer som tidligere har vært ignorert. Den feministiske filosofien er således både kritisk, (re)konstruktiv og nyskapende. Feministisk filosofi har som mål å forandre filosofien innenifra, slik at teorier og de praktiske konsekvensene som måtte følge av den, tilgodeser erfaringer, behov og interesser til begge kjønn. Feministisk filosofi utfordrer derfor tradisjonelle definisjoner og forestillinger, den problematiserer etablerte sjangerkrav og metoder. Denne disiplinen kan provosere, blant annet ved å sette filosofiske grunnlagsproblemer i fokus, for eksempel gjennom spørsmålet om hvorvidt filosofien virkelig er verdinøytral og allmenngyldig. En tenkning som utfordrer den tradisjonelle fagforståelsen på denne måten; som setter spørsmålstegn ved godt forankrede tradisjoner; som utfordrer fagets karakter, dets hovedlinjer og posisjoner; som fremsetter alternative begreper, perspektiver, teorier og metoder, er selvsagt omstridt.» ${ }^{41}$

Begrepet om en «feministisk epistemologi» refererer til den utfordrende alliansen av 
feminisme og filosofi, ifølge Alcoff og Potter (1993), som viser seg i dragkampen mellom det konkrete og generelle. «Forestillingen om en ekte eller egentlig epistemologi hopper bukk over premisset om at et generelt begrep om kunnskap, ett som avdekker klare og begrunnede standarder apriori, er mulig» ${ }^{42}$. Inga Bostad vektlegger den filosofiske skeptisismen som en retning innen filosofien som er inspirert av den feministiske epistemologien. Som Alcoff og Potter sier det: «Muligheten for et generelt og universelt begrep om kunnskapens natur og dens begrensninger, har ført mange feministiske filosofer til en form for skeptisisme, skeptisisme $\mathrm{i}$ forhold til et begrep om kunnskap som overser den sosiale konteksten og statusen til kunnskapssubjektet» ${ }^{43}$. Bostad understreker hvordan nettopp deler av den klassiske skeptisismen som vektlegger hverdagslivets erfaringer av det som holdes for sant og sikkert, kan brukes innenfor feministisk epistemologi: Samtidig som de hverdagslige erfaringer av at noe har en viss smak eller arter seg på et bestemt vis, er konkret og personlig, så er gyldighetsområdet ment å strekke seg ut til en generell filosofi om kunnskapens grenser.

Ifølge Bostad er det i dag ikke minst interessant å se hvordan feministisk orienterte jurister som Siobhan Mullally hevder at feminismen bør søke å gjenvinne universalismen gjennom diskursetikk og post-metafysikk. Hvilke argumenter er gyldige som begrunnelser for internasjonale regelverk om kvinners rettigheter i møte med for eksempel minoriteters rett til å praktisere en religion der kvinners rettigheter er underordnet eller brytes? I hvilken grad er det mulig å kritisere for eksempel kvinners generelle bruk av ansiktsdekkende slør samtidig som man forsvarer både ytringsfrihet og retten til å utøve sin re- ligion i praksis, leve i forhold til egen kultur og personlige overbevisninger samt retten til ikke å bli utsatt for nedverdigende behandling på grunn av tro, kulturell bakgrunn og levesett? I filosofien vil slike juridisk-moralske spørsmål også utfordre den feministiske filosofiens avgrensning av kvinner som gruppe; hvordan rangere ulike universelle rettigheter og verdier når kvinner med ulik kulturell, religiøs og sosial bakgrunn står opp mot hverandre? Feministiske filosofer som Seyla Benhabib har utvidet den feministiske filosofen ved blant annet å skille mellom to former for moralske orienteringer; den konkrete andre og den generaliserte andre. Omsorgsetikken er knyttet til den konkrete andre, mens rettighetsperspektiver er knyttet til den generaliserte andre. Ifølge Benhabib (1992) handler universalistiske teorier om hvordan medlemmer av en bestemt gruppe kan definere sine egne erfaringer som universelle og samtidig se bort fra den konkrete andre. Vi trenger en overskridelse av denne dikotomien, ifølge Benhabib, en «tredje vei» slik at vi kan se omsorg og rettigheter som en del av den samme virkeligheten.

\section{Metaforer for sjela og samfunnets antinomier}

De kvinnene vi har snakket med, søkte seg til filosofien fordi de i utgangspunktet var opptatt av de klassiske filosofiske spørsmål og hadde mindre engasjement for kjønnsrelaterte spørsmål og feministisk filosofi. Ingebjørg Seip skriver følgende: «Filosofi er det eneste faget hvor du ikke må slutte å spørre på et tidspunkt. For meg var det å få lov å forfølge det jeg utforsket, også der svarene aldri kunne bli entydige, veldig fasinerende. Det å ikke bøye av, men bli stående i det umulige i selve tankeprosessen, og slik undersøke tankens 
egne grenser, er filosofens privilegium». Seip skriver videre at «[j]eg tror filosofiske tanker ofte blir metaforer både for sjelas og samfunnets antinomier. Du skriver om noe abstrakt, teoretisk, og gjenkjenner plutselig din egen livssituasjon som skjulte mønstre i den teksten du skriver. Samtidig har jeg alltid også bevisst skrevet ut fra det som brenner for meg, det jeg syns er vanskelig og viktig å forstå. Jeg føler ofte at jeg bruker filosofi for å prøve å forstå mitt eget liv.»

«Kvinnene i norsk filosofi har bidratt positivt til at kvinne- og kjønnsrelevante emner er blitt innarbeidet i pensa i faget, til tverrfaglig akademisk diskusjon og til formidling gjennom foredrag og innlegg i radio, presse og TV», skriver Else Wiestad. Feministisk filosofi, fortsetter hun, har «store potensialer som kan videreutvikles samtidig som resultatene kan integreres i de fleste menneske-, miljø- og samfunnsrelaterte emnene i filosofi. Som sentralt og innovativt fagfelt bidrar feministisk filosofi/kjønnsteoretisk forskning til å utfordre, utvide og omdanne vårt menneskesyn, virkelighetssyn, verdisyn og vår normative tenkning (etikk).»

Ifølge Wiestad er en sentral oppgave fremover «å søke å forstå hva det er å være biopsykisk og kjønnet menneske i et bestemt geografisk, sosialt og kulturskapt miljø. Blant annet kan respektfull og nyutviklet verdi- og moralfilosofisk refleksjon bidra til å utvikle menneske- og samfunnssyn som fremmer likeverdige relasjoner mellom kjønn så vel som mellom sosiale og etniske grupper. Det er imidlertid ikke et mål at alle skal bli som oss (europeere). Vi trenger snarere en økt forståelse for andre kulturers miljøtilpassede levesett og verdisystemer.

Svenneby, på sin side, vektlegger språket: «Den sokratiske, kritiske undringen om folk som bruker ord egentlig har forstått hva de sier eller skriver, oppfatter jeg som en av filosofiens vedvarende viktigste oppgaver. Hva betyr et ord? Hvilken kontekst inngår det i? Hvilket annet ord kunne bedre uttrykke det språkbrukeren ønsker å uttrykke? Min motivasjon for å fortsette å studere filosofi kan dermed synes å ha forskjøvet seg fra kjønn til språk. Hvilke ord vi velger (eller har tilgang til) og hvordan språket vi bruker former våre oppfatninger om virkeligheten vi lever i er ikke nødvendigvis et kjønnsnøytralt tema, men hvis en filosof klarer å balansere sin tekst eller tale mellom det seriøse og det populære, det alvorlige og det morsomme, det velkjente og det metafysiske, spiller kjønn en mindre rolle. Det er fortsatt en viktig oppgave for filosofien å bidra med å gi motiverende innsikt i det paradoksale faktum at det ikke er samlingen av enkeltstående, velordnede og analyserbare elementer, men kreative, detaljrike og kaotiske partnerskap som bidrar til å holde en/s verden sammen.»

Filosofiens viktigste oppgave fremover beskrives slik av Ingebjørg Seip: «Det å holde oppe fleksibilitet i tanken og evne til å tenke omkring komplekse problemer er viktigere nå enn noen gang. Jo mer komplekst samfunnet blir jo mer tenderer diskursen mot å forenkle og skjematisere. Å øve opp evnen til å tenke komplekst, være kritiske til de sannhetene som tilbys og stille spørsmål ved de forutsetningene vi tar for gitt, er kjernen i en filosofisk praksis som arter seg forskjellig i forskjellige kulturelle kontekster, men som alltid vil være livsnødvendig for et fritt samfunn.»

\section{Vilje til å prioritere?}

Når vi skal forsøke å oppsummere de bidragene vi har fått fra kvinnelige filosofer i Norge, er det noen fellestrekk som blir tydelige; filosofiens åpenhet overfor nye perspektiver og 
dens evne og vilje til å strekke seg ut mot tverrfaglige problemstillinger, har vært viktig for både kvinnelige filosofer og for kjønnsteoretisk og feministisk innflytelse på den til enhver tid dominerende filosofien ${ }^{44}$. Den kontinentale filosofien blir også fremhevet som viktig for utviklingen av kjønnsteoretiske perspektiver i norsk filosofi. Det synes også å være en klar tendens til at tiltak som har vært iverksatt for å øke rekrutteringen av kvinner til faget og integrere kjønnsperspektiver, har vært kontroversielle og blitt møtt med til dels svært sterk motstand. Støtte utenfor de filosofiske instituttene - det være seg fra politikere, universitetene sentralt, kjønnsforskningsmiljøene eller media - synes å ha vært av helt avgjørende betydning for de endringer som tross alt har funnet sted når det gjelder rekrutteringen og integreringen av kvinne- og kjønnsperspektivene i norsk filosofi.

$\mathrm{Vi}$ tror mangelen på integrering av kjønnsperspektiver i filosofifaget i Norge og den påfallende lave andelen av kvinner i filosofifaget $\mathrm{i}$ «et av verdens mest likestilte land» henger nøye sammen. Så lenge feministisk filosofi og bidrag av kvinnelige filosofer er marginalisert eller fraværende, vil den skjeve kjønnsbalansen i faget trolig ikke endres. Mangelen på kjønnsperspektiver har blitt etterlyst av ulike grupper gjentatte ganger, og mye tyder på at det nettopp er møte med kjønnsperspektiver og kvinnelige filosofer både på pensum og i klasserommene som gir mange kvinner lyst til å fortsette filosofistudiet, slik for eksempel Owesen påpeker i møtet med Beauvoir-teksten.

Muligheten for å styrke den feministiske filosofien, og dermed øke rekrutteringen av kvinner ved de ulike lærestedene, er samtidig tilstede. I Forskningsrådets rapport ${ }^{45}$ pekes det for eksempel på at feministisk filosofi er et lite fagområde i Norge, det består kun av en håndfull forskere. Likevel publiseres det både nasjonalt og internasjonalt, og kvaliteten på publikasjonene innen feltet er gode, i følge Forskningsrådet. ${ }^{46}$ Mortensen skriver at «... a handful of scholars from Norway have managed to make themselves heard as marginal but distinct voices in a few niches of feminist philosophy». ${ }^{47}$ Gitt at det også finnes et tverrfaglig miljø for kjønnsforskning i Norge, heter det videre i Forskningsrådets rapport, antas det å være gode muligheter for vekst innenfor dette området av norsk filosofi.

En slik vekst tror vi kan bidra til økt rekruttering av kvinner til faget. Muligheten for vekst og integrering av kjønnsperspektiver - og dermed for økt rekruttering av kvinner til filosofifaget i Norge - er altså til stede. Spørsmålet er om det også finnes vilje ved de enkelte filosofiske instituttene til å prioritere, oppvurdere og integrere kjønnsperspektiver, og dermed også bryte mannsdominansen og kjønnsblindheten som har preget faget i hele etterkrigstiden. Dette er viktig blant annet fordi den sterke underrepresentasjonen av kvinner hemmer utviklingen av filosofifaget; faget blir både smalt og fordreid når kvinners perspektiver ekskluderes. Kjønnsubalansen i filosofi er imidlertid ikke noe som kun angår de enkelte filosofiske instituttene. Den nåværende situasjonen undergraver også lik tilgang til høyere utdanning, og hindrer utviklingen av potensielle intellektuelle ressurser. Dette er ikke bare et demokratisk problem, og heller ikke kun et spørsmål om rettferdighet. Det innskrenker ikke bare filosofifaget, men det svekker også kvaliteten og resultatene av høyere utdanning og forskning generelt. 


\section{Bibliografi:}

Alcoff, Linda, and Elizabeth Potter (eds.) (1993). Feminist Epistemologies, New York: Routledge.

Anderson, Elizabeth (1995). «Feminist Epistemology: An Interpretation and Defense». Hypatia, 10: 50-84.

Aristoteles (2007). Politikk. Oversatt av Tormod Eide, Oslo: Vidarforlaget.

Aristoteles (2009). Politics. A Treatise on Government. Gutenberg ebook. www.gutenberg.org

Beauvoir, Simone de (2000). Det annet kjønn. Oversatt av Bente Christensen. Oslo: Pax Forlag A/S.

Benhabib, Seyla (1992). Situating the self. Cambridge: Polity Press.

Benhabib, Seyla, Judith Butler, Drucilla Cornell and Nancy Fraser (1995). Feminist Contentions, New York: Routledge.

Bondevik, Hilde og Lina Rustad (1999). Kjønnsperspektiver i filosofibistorien. Oslo: Pax forlag A/S.

Bostad, Inga, (1995). Filosofi på norsk 1. Oslo: Pax forlag $\mathrm{A} / \mathrm{S}$.

Bostad, Inga (1997). Filosofi på norsk, II. Oslo: Pax forlag A/S.

Bostad, Inga og Elin Svenneby. (1993). Gender - an issue for philosophy? Nordic Network of Women in philosophy. Oslo: Universitetet i Oslo.

Butler, Judith (1990). Gender Trouble, New York: Routledge.

Granly Meldalen, Sindre (2005). «Kjønnsproblemer på filosofi». I Universitas, 7. desember 2005. http://universitas.no/kultur/47140/kjonnsproblemer-pa-filosofi [Lesedato 21. september 2015].

Harding, Sandra (1991). Whose science? Whose knowledge? Ithaca, N.Y.: Cornell University Press.
Kuhn, Thomas S. (1962). The Structure of Scientific revolutions, University of Chigago press.

Mortensen, Ellen (2009). «Feminist Philosophy in Norway, with a View to the Other Nordic Countries». I Signs. Journal of Women in Culture and Society, vol. 34, no 2, s. 239-247.

Nerheim, Hjørdis (1991). Kvinneperspektivet i filosofien - Premisser for å forstå den moderne kvinnens situasjon. Oslo: Novus forlag.

Nickelsen, Trine (2001). «Ingen kvinner ved Avdeling for filosofi. Hvorfor?» I Uniforum 28. mai 2001. http://www.uniforum.uio.no/nyheter/ 2001/05/ingen-kvinner-ved-avdeling-for-filosofihvorfor.html [Lesedato 21. september 2015].

Okin, Susan Moller (1989). Justice, Gender, and the Family, New York: Basic Books.

Owesen, Ingeborg (2010). «Om å kanonisere det som har unndratt seg kanonisering: Feminisme og filosofihistorie». I Norsk filosofisk tidsskrift, nr. 4, 2010.

Pettersen, Tove (2011). Filosofiens annet kjønn. Oslo: Pax forlag A/S.

Skirbekk, Gunnar (1995). «Vi er mange - og aparte. Kunnskapssosiologiske funderingar om filosofi og politikk» i Inga Bostad (red) Filosofi på norsk, 1. Oslo: Pax forlag A/S.

Skjervheim, Hans (1992). Filosofi og dømmekraft. Oslo: Universitetsforlaget.

Songe-Møller, Vigdis (1999). Den greske drømmen om kvinnens overflødighet. Oslo: Cappelen.

Wiestad, Else (1994). De store hundreärsbølgene: kjønnsdebatten gjennom 300 år. Oslo: Emilia Press.

Wiestad, Else (2010). «Hvor ble det av kvinnene?» Norsk filosofisk tidsskrift, 2010, vol 45.

3 Kilde er StudentTorget.no: http://studenttorget.no/index.php? show $=22$ \&artikkelid $=14638$ [Lesedato 3. oktober 2015].

4 Kilde er Forskerforum: http://www.forskerforum.no/wip4/historisk-mannsbastion/ d.epl?id=2119710 [Lesedato 3. oktober 2015].

5 Else Wiestad, Elin Svenneby, Ingeborg Owesen og Ingebjørg Seip har alle svart på følgende spørsmål: 
Hva var det som motiverte deg til å starte med filosofi?

Hva kjennetegnet miljøet på filosofi under din studietid?

Hvordan har dine egne erfaringer preget ditt intellektuelle arbeid?

Er filosofien etter din oppfatning normativ og/eller deskriptiv?

Hvordan har kvinnene i norsk filosofi preget utviklingen i og utenfor akademia?

Hvilke deler av filosofien er du mest opptatt av? Hvilke filosofiske problemer finner du mest utfordrende?

Hvilken rolle spiller feministisk filosofi i det norske filosofimiljøet?

Hva kan feministisk filosofi tilføre filosofifaget?

Hva arbeider du med akkurat nå?

Hvordan vil du beskrive filosofiens viktigste oppgave i dag?

Svarene vi fikk på disse spørsmålene utgjør noe av materialet i artikkelen. I tillegg har vi hentet inn kommentarer og refleksjoner fra Synnøve des Bouvrie, Vigdis Songe-Møller og Kristin Sampson. Vi gir ikke en fullstendig oversikt over kvinner i norsk filosofi. Det er mange som gjennom de siste 20-30 årene har bidratt til fagets utvikling, men som det faller utenfor denne artikkelen å omtale.Vi har også benyttet oss av informasjon fra Statistisk sentralbyrå, Nordisk institutt for studier av innovasjon, forskning og utdanning, tidligere publiserte intervjuer og artikler, samt våre egne erfaringer og refleksjoner. Artikkelen «Kjønn og feminisme i norsk filosofi» gir ikke et fullstendig bilde av denne tematikken, det finnes sikkert relevante hendelser, nyanser, personer og publikasjoner som ikke blir omtalt her. Innenfor rammene av de kilder vi har hatt tilgang til, samt NFTs sideantall og tidsrammer, mener vi likevel at artikkelen gir et bilde av noen klare og viktige tendenser i norsk filosofi.

6 Eventuelt ukjønnede (et tredje kjønn). Begrepet «Det tredje kjønn» brukes om mennesker som ikke anses eller anser seg som hverken kvinne eller mann. I det følgende vil vi derimot holde oss til det mer tradisjonelle skille mellom kvinne og mann.

7 Beauvoir, Simone de (2002). Det annet kjønn. Oversatt av Bente Christensen. Oslo: Pax Forlag A/S; Okin, Susan Moller (1979). Women in Western Poltical Thought. Princeton, New Jersey: Princeton University Press; Holm, Ulla M (1999). «Autoritetens temperatur - Aristoteles om kjønn». I Kjønnsperspektiver i filosofihistroien, Bondevik. H. og Linda Rustad (red.). Oslo: Pax Forlag.
8 Eldre etablerte forskere ble i Tromsø utfordret og angrepet av den yngre garde, anført av filosofimiljøet, ifølge Synnøve des Bouvrie. «Da universitetet i Tromsø skulle utforme sine målsettinger og styringsformer, førte det blant annet til en debatt i Universitetstinget («kollegiet») som varte i to dager, over spørsmålet om hvorvidt ex.phil.-studiet skulle bygge på marxistisk ideologi eller være "pluralistisk».

9 Innen medisinsk forskning har flere studier vist hvordan kjønnsperspektiver fører til nye metoder, som igjen fører til ny empiri og endrede tolkninger, som igjen fører til at kunnskapsfeltet endrer seg (f.eks. i studier av primater og hjerteinfarkt). IoSkirbekk 1996, 29.

I I Skirbekk ibid.

I 2 Bostad 1995, 30.

I3 Bostad 1995, 91.

I4 De følgende sitatene fra Wiestad er hentet fra svar på de spørsmålene vi har sendt i forbindelse med innhenting av materiale til denne artikkelen - se note 5 . I 5 Felix, Cathrine. 2011. «Hvem er kvinnene i norsk filosofi?» Salongen. Nettstedet for filosofi og idéhistorie. 7. mars 2011. http://www.salongen.no/ ? $\mathrm{p}=816$ [Lesedato 21. september 2015].

I6 Magistergraden til Laura Grimm fra 1941 hadde tittelen «Oppfatninger av ironi fra Aristoteles frem til i dag».

I7 Nekrolog Aftenposten 18.1.2015 av Inga Bostad, Dagfinn Føllesdal og Else Wiestad.

I8 De følgende sitatene fra Owesen er hentet fra svar på de spørsmålene vi har sendt i forbindelse med innhenting av materiale til denne artikkelen - se note 5 . I9 Elster, Jon. 2013. «Den uforståelige Latour». I Aftenposten 24. april 2013. http://www.aftenposten.no/meninger/Den-uforstaelige-Latour7183458.html [Lesedato 22. september 2015]. 20 De følgende sitatene fra Svenneby er hentet fra svar på de spørsmålene vi har sendt i forbindelse med innhenting av materiale til denne artikkelen - se note 4

2I Sitatene fra de Bouvrie er hentet fra kommentarer til tidligere versjon av denne artikkelen.

22 Thorolvsen, Anita K.L. 2000. «Kjønnsbalanse eller misforstått kvinnehjelp». Bladet Forskning november 6/2000. forskningsradet.no/ bladetforskning/Nyheter/ Kjonnsbalanse_eller_misforstatt_kvinnehjelp/ 1250810470279 [Lesedato 4. oktober 2015].

23 Ericsson Ryste, Marte 2007. «Universitetene vil øremerke». I kifino.no http://kifinfo.no/c62435/nyhet/ vis.html?tid=47506 [ Lesedato 4. oktober 2015). Grønli Strausheim, Kristin. 2003. «Slutt på øremer- 
king av kvinneprofessorater». I Forskning.no. http:/ /forskning.no/om-forskning-likestilling-forskningspolitikk-seksualitet/2008/02/slutt-pa-oremerking-av [Lesedato 4 oktober 2015].

Johansen, Marianne. 2002. «Lovstridig likestilling» . I Universitas 6. februar 2002.

24 Tidemann, Grethe. 2001. «Diskriminering eller god likestillingspolitikk». I Uniforum 3. oktober 2001. http://www.uniforum.uio.no/nyheter/ 2001/10/diskriminering-eller-god-likestillingspolitikk.html [Lesedato 4. oktober 2015] http:// www.neitileu.no/om_nei_til_eu/politikk/uttalelser/likestilling_ut_av_eoes

25 Nickelsen, Trine. 2001. «Ingen kvinner ved Avdeling for filosofi - hvorfor?». I Uniforum 28. mai 2001. http://www.uniforum.uio.no/nyheter/ 2001/05/ingen-kvinner-ved-avdeling-for-filosofihvorfor.html [Lesedato 4. oktober 2015].

26 Oppsummeringen er skrevet av Edle Stang, og er tilgjengelig her: https://www.hf.uio.no/for-ansatte/aktuelt/hf-aktuelt/2007/uke5/kjonnsfordeling.html

27 Granly Meldalen 2005.

28 Rapporten er tilgjengelig her, og disse opplysningene står på side 22. http://www.forskningsradet.no/servlet/Satellite?blobcol=urldata\&blobheader=application \%2Fpdf\&blobheadername1 $=$ Content-Disposition $\% 3 \mathrm{~A} \&$ blobheadervalue 1 $=+$ attachment $\% 3 \mathrm{~B}+$ filename $\% 3 \mathrm{D} \% 22$

PhilosophyandhistoryofideasinNorwaypdfversion.pdf\%22\&blobkey=id\& blobtable=MungoBlobs\&blobwhere $=1274462260561 \&$ \&sbinary $=$ true

29 Felix, Cathrine. 2010. «Hvor er kvinnene i norsk filosofi». Salongen. no 24. november 2015. http:/ /www.salongen.no/?p=766 [Lesedato 4. oktober 2015]. Felix nevner blant annet at det er viktig å få kvinner inn på pensum, og at utstillingen «Filosofiens annet kjønn» presenterte mange kvinnelige filosofer som kan gå inn på pensum. Hun sier videre at det å gi de mannlige filosofene selskap ved for eksempel å henge opp bilder av kvinnelige filosofer på instituttets vegger, kan være et viktig tiltak. Høsten 2015 mottok Institutt for filosofi, idé- og kunsthistorie og klassiske fag et tilbud om å overta denne utstillingen, og gi den en perma- nent plass i deres lokaler. Tilbudet ble avslått, og begrunnelsen var at "den ikke egner seg» som «permanent utsmykking».

3o Flemmen, Haakon. 2011. «Færre kvinner tar doktorgraden». Salongen 9. mai 2011. http://www.salongen.no/?p=837 [Lesedato 4. oktober 2015.

3 I Kvinners underrepresentasjon i filosofi er ikke bare et fenomen i Norge, tilsvarende utfordring finnes i andre land både i og utenfor Norden. American Philosophical Association har for eksempel en egen komité som skal evaluere og rapportere om kvinners status ved filosofiske institutter i USA. På nettsidene deres finnes mange ressurser tilgjengelig: http://www.apaonlinecsw.org/mission 32 Mortensen 2009.

33 (ibid)

34 Intervjuet «Ti år med Kjønn og filosofi», som ble utført av Amund Radke Hoffart, kan leses i sin helhet i Bulletine 2-2014 http://www.stk.uio.no/ forskning/aktuelt/bulletine/utgaver/2014-2/

35 Forskningsrådets rapport fra 2010, «Evaluering av forskning i filosofi og idehistorie», s 40.

36 Warren, Karen. 2009. An Unconventional History of Western Philosophy. Landham, Maryland: The Rowman \& Littlefield Publishing Group, Inc.

37 De følgende sitatene er hentet fra nyskrevet bidrag til denne artikkelen.

38 Kilde: http://www.uib.no/bnkf

39 http://kifinfo.no/c60892/seksjon.html?tid=60893

40 Sitatet er hentet fra intervjuet «Ti år med Kjønn og filosofi» Bulletine 2-2014 http:// www.stk.uio.no/forskning/aktuelt/bulletine/utgaver/2014-2/

4 I Pettersen, Tove. 2011. Filosofiens annet kjønn. Oslo: Pax forlag A/S, s. 10-11.

42 Side 1 , oversatt av Inga Bostad.

43 (ibid)

44 Det er også viktig å legge til at litteraturvitere som Ellen Mortensen og Toril Moi har kommet med bidrag som har blitt integrert og diskutert blant norske feministiske filosofer - ikke minst Toril Mois arbeider om Simone de Beauvoir. 452010 s. 60

46 Forskningsrådets rapport fra 2010, «Evaluering av forskning i filosofi og idehistorie», s. 60.

47 Mortensen, Ellen. 2009, 239. 